\title{
Morphometric differentiation and sexual dimorphism in Limnomedusa macroglossa (Duméril \& Bibron, 1841) (Anura: Alsodidae) from Uruguay
}

\author{
Valeria de Olivera-López ${ }^{1 *}$, Arley Camargo², Raúl Maneyro ${ }^{1}$ \\ ${ }^{1}$ Laboratorio de Sistemática e Historia Natural de Vertebrados, Instituto de Ecología y Ciencias Ambientales, Facultad de Ciencias, \\ Universidad de la República, Iguá 4225, Montevideo 11400, Uruguay \\ ${ }^{2}$ Centro Universitario Regional Noreste, Sede Rivera, Universidad de la República, Ituzaingó 667, Rivera 40000, Uruguay \\ *Corresponding author. E-mail address: vdeolivera@fcien.edu.uy
}

Submitted on: 2020, $18^{\text {th }}$ June; revised on: 2021, $9^{\text {th }}$ March; accepted on: 2021, $21^{\text {st }}$ March Editor: Raoul Manenti

\begin{abstract}
Intersexual morphological differences within a species occur in many traits, including body size and shape. Many processes that cause geographic variability in morphology have been proposed: population structure, phenotypic plasticity (environmental effects on development), and natural and/or sexual selection. Several hypotheses can explain patterns of sexual dimorphism in anurans, including natural or intra/inter-sexual selection, and differences in life history strategies between sexes. Limnomedusa macroglossa is considered a habitat specialist restricted to rocky outcrops in Brazil, Argentina, Paraguay, and Uruguay. We evaluated the extent of sexual (size and shape) dimorphism in L. macroglossa from Uruguay based on morphometrics and secondary sexual characteristics, while taking into account geographic variation. Sexual dimorphism in body size of adults was found, but multivariate analyses did not demonstrate the existence of significant differences in shape. There were also significant differences in body size and hind leg measurements among six hydrographic basins as a result from the phenotypic plasticity correlated with local temperature, representing a clinal variation along the latitudinal gradient of Uruguay. The sexual dimorphism found in body size is probably the consequence of higher growth rates and/or late sexual maturity in females, which favors larger body size for accommodating larger ovaries, and thus, higher reproductive output.
\end{abstract}

Keywords. Sexual dimorphism, clinal variation, morphometrics, Limnomedusa macroglossa, Uruguay.

\section{INTRODUCTION}

Morphology is one of the main components of the phenotype that can be studied through qualitative as well as quantitative characteristics. In particular, morphology can be assessed via morphometrics to quantitatively describe, analyze and interpret morphological variation within and between species (Kaliontzopoulou, 2011; Rohlf, 1990). Morphological quantitative traits are usually polygenically inherited and show considerable plasticity in relation to environmental factors (Babik and Rafinski, 2000). Furthermore, plasticity can lead to geographic variability in morphology. In that sense, many processes have been proposed, such as: biogeographical barriers that partially isolate populations, effects of environmental parameters (precipitations and temperature) on growth rates, and action of sexual selection resulting in sexual dimorphism (Schäuble, 2004). Body size is a strongly plastic morphological trait (Green, 2015) fundamental in physiological and ecological contexts. Traditionally, snout-vent length (SVL) has been used as the gold standard to measure body size in frogs (Kupfer, 2007). Among anurans, analyses of intraspecific geographical variability in morphology have often revealed extensive variation in body size (Schäuble, 2004). Due to the limited dispersal ability and high philopatry in frogs, it is common to find 
intraspecific differences in morphology among geographically separated populations, particularly in body size, caused by genetic divergence among isolated populations (Baraquet et al., 2012; Castellano et al., 2000). In addition to geographic distance, landscape features could account for spatial morphological variation. For instance, hydrographic basins could act as physical barriers promoting isolation and spatial structuring among populations as a result of changes in altitude, slope and landscape features among basins. Moreover, climate and food availability may also vary geographically, leading to differences in the ability to grow, resulting in morphological variation (Lovich and Gibbons, 1992; Hartmann, 2016).

Another source of intraspecific variation could be sexual dimorphism; the occurrence of morphological differences between individuals of different sex within a species, may affect several traits like body size, shape and sometimes, secondary sexual characteristics (Wells, 2007). Several factors can influence sexual dimorphism including female reproductive strategy, sexual selection, and competition for resources (Fathinia et al., 2012). Sexual dimorphism may have important consequences for animal ecology, and is a key aspect for understand the evolution of life history traits (Kupfer, 2007). In particular, sexual size dimorphism (SSD) is defined as the difference in body length or mass of sexually mature males and females (Fairbairn, 1997; Kupfer, 2007; Nali et al., 2014). Several evolutionary processes have been proposed to explain patterns of sexual dimorphism in anurans. On one hand, the usually biased SSD in favor of females (Shine, 1979) is hypothesized as the result of a fecundity advantage driven by natural selection: bigger females can harbor more eggs, and then produce larger clutches (Arak, 1988; Wells, 2007). Whereas in males, natural selection operates against of bigger body sizes, because higher vulnerability of prolonged breeders to predators increase their cost of reproduction in terms of survival at small body sizes (Camargo et al., 2008). On the other hand, some authors argue that sexual dimorphism is a consequence of sexual selection. In this sense, Darwin envisioned that sexual selection depends on the struggle between males to access females, and recognized two mechanisms: intrasexual selection, through competition between members of the same sex (usually males) for access to mates, where large males defeat small ones in aggressive encounters and displace them from territories; and intersexual (epigamic) selection, where members of one sex (usually females) choose members of the opposite sex, by comparing traits of potential mates and select those that are more attractive (Darwin, 1871; Shine, 1979; Woolbright, 1983; Arak, 1988; Lovich and Gibbons, 1992). However, some authors proposed that sexual dimorphism is a function of differences in life history strategies between the sexes, as well as the result of a variety of selective forces. In this sense, SSD can be explained in terms of disparate age structure between sexes in reproductive populations; that is, females were larger because they were older than the males, which mature earlier at smaller size. In fact, Monnet and Cherry (2002) found that age differences between breeding males and females appear to have a major influence on the extent of dimorphism. Female anuran fecundity appears to be correlated with body size in all anuran species in which this phenomenon has been investigated, and, as anurans display indeterminate growth (Halliday and Verrell, 1986), this could be expected to lead to faster growth rates and delayed reproduction in females (Monnet and Cherry, 2002).

Limnomedusa Fitzinger 1843, is the most basal genus within the family Alsodidae (Frost et al., 2006; Pyron and Wiens, 2011). The only species of the genus, "rapids frog" Limnomedusa macroglossa (Duméril and Bibron, 1841), is a generalist insect predator of medium to large size, with shades of brown-and-gray and conspicuous glands in the back, and an immaculate white belly (Maneyro and Carreira, 2012). As secondary sexual characteristics, males present a single vocal sac and dark nuptial pads on their fingers. It is a habitat specialist, with a restricted distribution in rocky outcrops of basaltic origin and superficial soils, with or without vegetation (Maneyro and Carreira, 2012). Regarding its geographic variation in Uruguay, larval dispersion appears to be connecting separate major basins via watercourses, although it is also likely that adults disperse between habitat patches by land. As a corollary, an isolation pattern by distance was established, which maintains population stability and genetic diversity in northern populations (Fernández, 2016).

Recently, de Olivera et al. (2018) found a correlation between body size and ovarian mass in populations of Limnomedusa macroglossa from Uruguay, suggesting a fecundity advantage for larger females since they can accommodate larger ovaries. Moreover, they also reported a prolonged pattern of reproduction for this species, which is usually associated with higher levels of intra/ inter-sexual selection (Wells, 2007). Further, in populations from Rio Grande do Sul state, SSD has been found, where females attain larger SVL than males, and they also classified the pattern of reproduction as prolonged, although highly seasonal (Kaefer et al., 2009).

Its geographic distribution includes the south of Brazil (from Paraná to Rio Grande do Sul), the northeast of Argentina (Misiones and Entre Ríos), the southeast of Paraguay (Alto Paraná), and almost the entire Uruguayan territory (Frost, 2020). However, despite being a relatively 
common species, geographical variation in morphology has not been investigated in L. macroglossa overall distribution. This circumstance is relevant since most of the distribution range occurs in Uruguay, and thorough evaluation of the morphological variation across such distribution is necessary given its latitudinal, environmental gradient. Lastly, in reference to its conservation status, is categorized nationally and globally as Least Concern according to the IUCN criteria (Silvano et al., 2004; Maneyro et al., 2019).

The aim of this work was to evaluate the occurrence of sexual (size and shape) dimorphism in Limnomedusa macroglossa based on morphometrics and secondary sexual characteristics across populations from Uruguay.

We hypothesized that:

(1) Sexual dimorphism and minimum size at sexual maturity (MSSM) are important life history traits due of their value in reproductive output of a species. Besides, most anuran females have larger body sizes than males (female biased SSD) and, thus, females usually reach sexual maturity at larger sizes.

(2) Isolation pattern by distance triggered by hydrographic basins favor geographical differences in morphology.

From which the following predictions emerge:

(1.1) we expect that L. macroglossa present sexual size dimorphism with females larger than males, and in fact, with females reaching MSSM at bigger sizes than males.

(2.1) Finally, hydrographic basins, due to environmental differences, will favor a greater morphological differentiation in L. macroglossa between than within basins.

\section{MATERIALS AND METHODS}

\section{Field data collection}

We hand-captured 180 individuals of Limnomedusa macroglossa between January 2012 and March 2015, of which 102 were juveniles, 34 mature females and 44 mature males. The individuals were collected along a latitudinal gradient of six hydrographic basins from Uruguay (based on Achkar et al., 2013): Río Uruguay ( 7 females and 8 males), Río Santa Lucía (3 females and 4 males), Océano Atlántico (2 males), Laguna Merín (3 females and 1 male), Río de la Plata (6 females and 6 males), and Río Negro (11 females and 14 males) (Fig. 1) (see Appendices 1, 2 and 3). Latitude and longitude location data of these individuals were obtained from a GPS (Garmin, eTrex 20). In addition, 13 individuals not georeferenced (4 females and 9 males) were also used for SSD and SMA analyses. Lastly, juvenile individuals were used in another investigation (Fernández, 2016).

All collected individuals were euthanized using topic lidocaine and intraperitoneal injection of sodium pentobarbital

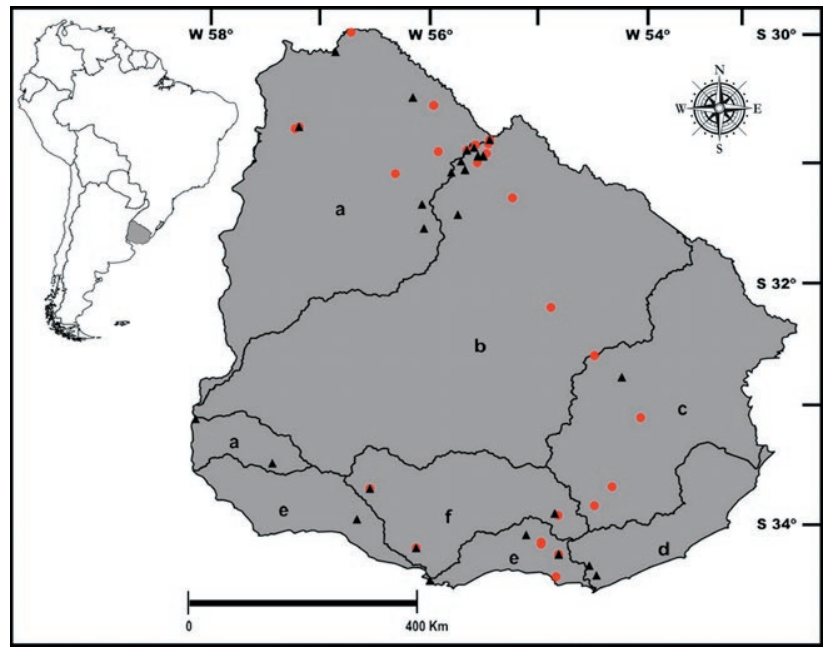

Fig. 1. Maps of South America and Uruguay showing basins where Limnomedusa macroglossa was sampled for analyses of geographic variation in sexual dimorphism and morphometric differentiation. Names of sampling basins are as follows: $\mathrm{a}=$ Río Uruguay, $\mathrm{b}=$ Río Negro, c = Laguna Merín, d = Océano Atlántico, e = Río de la Plata and $\mathrm{f}=$ Río Santa Lucía. Black triangles are males and red circles are females (based on Achkar et al., 2013).

( $0.5 \mathrm{ml}$ of a $0.2 \mathrm{~g} / \mathrm{ml}$ solution), fixed with $10 \%$ formaline, and preserved in $70 \%$ ethanol, following the experimental protocol "Euthanasia method for amphibians and reptiles in the field" approved by the Institutional Animal Care and Use Committee (IACUC), Faculty of Science, University of the Republic. Individuals were euthanized with the purpose of being genetically studied by Fernández (2016), therefore in this work, those individuals were reused. All the specimens are stored in the Vertebrate Zoology Collection (ZVC-B) of the Faculty of Sciences, University of the Republic.

We measured eleven morphometric variables using a digital calliper $(0.01 \mathrm{~mm}$ precision) by a single observer for consistency (Grenat et al., 2012): snout-vent length (SVL), mandibular width (MW), head length (HL), inter-orbital distance (IOD), eye diameter (ED), inter-narial distance (IND), eye-nostril distance (END), arm length (ARML), tibia length (TiL), tarsus length (TaL) and metatarsus length (MtL). We followed the methodology of Duellman (1970) to obtain the measurements of SVL, IOD, ED, IND, TiL, and MtL, as well as Napoli (2005) for END, and Greene and Funk (2009) for ARML. Finally, we measured TaL as the straight length of the tarsus, MW as the straight line between oral commissures, and HL as the straight line distance from the posterior edge of the skull to the tip of the snout. All individuals were measured twice to ensure accuracy and all measurements were taken on the right side of the body (Fig. 2).

For each individual, sex and maturation status (juvenile/ adult) were determined by gonadal analysis. Additionally, males were considered mature by the presence of nuptial pads in their fingers. Finally, to infer MSSM on each sex, we pooled all individuals from all basins and register the size of the adult male/ female with the lowest SVL. 


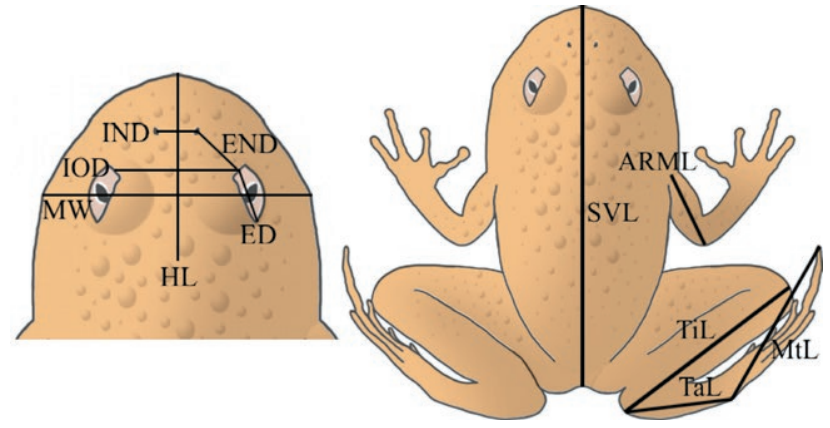

Fig. 2. Morphometric measurements used for the analysis of sexual dimorphism in Limnomedusa macroglossa (Anura: Alsodidae) from Uruguay: SVL = snout-vent length; $\mathrm{MW}=$ mandibular width; $\mathrm{HL}$ = head length; $\mathrm{IOD}=$ inter-orbital distance; $\mathrm{ED}=$ eye diameter; IND = inter-narial distance; END = eye-nostril distance; ARML $=$ arm length; $\mathrm{TiL}=$ tibia length; $\mathrm{TaL}=$ tarsus length and $\mathrm{MtL}=$ metatarsus length.

\section{Data analysis}

Using the morphometric variables, we tested for sexual dimorphism and quantified morphometric variation through univariate and multivariate analyses while taking into account geographic distribution.

To remove allometric effects of body size in the sexual dimorphism analyzes we applied the transformation proposed by Lleonart et al. (2000), which scales all individuals to same size and adjust their shape to that they would have in the new size.

For all the variables we tested the normality (Lilliefors' test) and homogeneity of the variance (Levene's test) of raw and transformed data. A priori, the raw data did not reject the hypotheses of normality neither homogeneity of variances. Although, with the transformed data, there were rejected. No outlier individuals were found in the analyzed sample.

We performed a t-test to evaluate for a significant difference in SVL between males and females. Sexes were also compared through one-way perMANOVA using Euclidean similarity index. As differences in body size between sexes are not always related to SVL and can involve body parts used in various behavioral contexts (Kupfer, 2007), we conducted multivariate analyses. Differences in shape between males and females were examined through a Principal Component Analysis (PCA) using the Variance-Covariance matrix, and a Hierarchical Cluster with Unweighted Pair-Group Average algorithm and Euclidean similarity index with 9999 pseudoreplicates.

SVL, MtL and TiL variables were log-transformed to estimate standardized mayor axis (SMA) regression slopes. This method estimates the line of best fit (slope) when both variables are measured with error (Falster et al., 2006; Warton et al., 2006). We estimated the SMA relationship between SVL and $\mathrm{MtL} / \mathrm{TiL}$. We tested for significant allometry assuming the null hypothesis that the slope was equal to 1 (isometry), performed slope comparisons between sexes, tested for shifts along the common SMA slope and in elevation of slope between sexes using Wald test, with 1000 iterations and critical P-value to 0.05.
To evaluate morphometric variation, we analyzed differences among basins by one-way perMANOVA (using Bonferroni correction for P-values) and PCA, based on raw measured variables, because our goal was also to evaluate the effect of body size, and we box plot SVL, TiL and MtL variables according to basins. In addition, we calculated the average leg length (= $\mathrm{TiL}+\mathrm{TaL}+\mathrm{MtL}$ ) among individuals belonging to each basin. Finally, we tested for significant differences in the leg length and SVL among basins through t-test. The latitude vs. SVL relationship was evaluated through regression analysis (using Reduced Major Axis algorithm). In these analyses we used 35 mature males and 30 mature females because coordinate data were not available for all individuals.

We used the freely available online programs PAST 3.21 (Hammer et al., 2001), GNUMERIC 1.12 (The Gnome Project, 2018), SMATR 2.0 (Falster et al., 2006) and QGIS 18.24 (QGIS Development Team, 2016) for all statistical analyses performed in this work.

\section{RESULTS}

\section{Sexual dimorphism}

In total, we examined 180 specimens of which 102 were juveniles, 34 mature females and 44 mature males. We found dark nuptial pads in the first, second, and sometimes, the third fingers of all mature males (Fig. 3). We found that females longer than $49.82 \mathrm{~mm}$ and males longer than $41.29 \mathrm{~mm}$ in SVL were sexually mature (i.e., nuptial pads in males and fully-developed oocytes in females). Taking this into account, we set the MSSM in females at $49.82 \pm 0.01 \mathrm{~mm}$ and in males at $41.29 \pm 0.01 \mathrm{~mm}$.

Significant differences in mature body size were found between sexes. Mature females had an average SVL $(56.99 \pm 4.27 \mathrm{~mm})$ significantly higher than that of mature males $(49.69 \pm 4.73 \mathrm{~mm})(\mathrm{t}=7.04, \mathrm{P}<0.001)$.
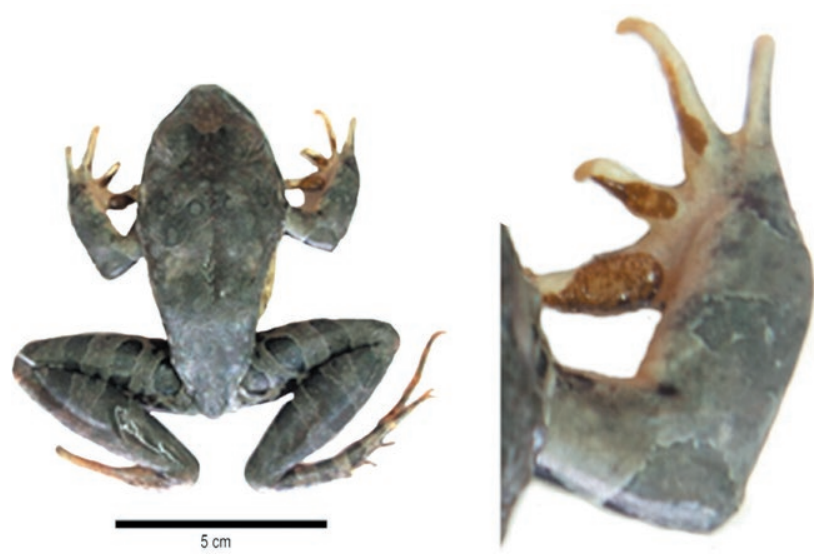

Fig. 3. Male displaying dark nuptial pads above fingers of the foreleg (ZVC-B 23281). 
Table 1. Descriptive statistics of each morphological variables measured in Limnomedusa macroglossa (Anura: Alsodidae) from Uruguay. Morphological differences between sexes were tested for each variable through $\mathrm{t}$ test. Sex: $0^{n}=$ male, $ᄋ=$ female; $\mathrm{n}$ : sample size; Min: minimum value; Max: maximum value; x: mean; SE: standard error; SD: standard deviation; Vc: variance coefficient. Variables for which significant differences were obtained are in bold. All measurements are shown in millimeters.

\begin{tabular}{|c|c|c|c|c|c|c|c|c|c|c|}
\hline & Sex & $\mathrm{n}$ & Min. & Max. & $\mathrm{x}$ & SE & $\mathrm{SD}$ & Vc. & $\mathrm{t}$ test & $P$ value \\
\hline \multirow[t]{2}{*}{ SVL } & $\sigma^{7}$ & 44 & 41.29 & 60.92 & 49.69 & 0.71 & 4.73 & 9.51 & 7.04 & $<0.001$ \\
\hline & ㅇ & 34 & 49.82 & 64.25 & 56.98 & 0.73 & 4.27 & 7.5 & & $<0.001$ \\
\hline \multirow[t]{2}{*}{ MW } & $0^{1}$ & 44 & 16.61 & 24.28 & 19.66 & 0.29 & 1.94 & 9.87 & 6.56 & $<0.001$ \\
\hline & 우 & 34 & 19.7 & 24.47 & 22.32 & 0.26 & 1.54 & 6.92 & & $<0.001$ \\
\hline \multirow[t]{2}{*}{$\mathrm{HL}$} & $0^{7}$ & 44 & 14.47 & 20.98 & 17.13 & 0.23 & 1.53 & 8.96 & 6.78 & $<0.001$ \\
\hline & 웅 & 34 & 16.95 & 22.02 & 19.46 & 0.25 & 1.46 & 7.51 & & $<0.001$ \\
\hline \multirow[t]{2}{*}{ IOD } & $0^{x}$ & 44 & 7.05 & 9.82 & 8.38 & 0.12 & 0.79 & 9.44 & 5.71 & $<0.001$ \\
\hline & 우 & 34 & 8.2 & 10.93 & 9.4 & 0.13 & 0.77 & 8.15 & & $<0.001$ \\
\hline \multirow[t]{2}{*}{ ED } & $0^{7}$ & 44 & 4.17 & 7.2 & 5.45 & 0.1 & 0.69 & 12.59 & 4.27 & $<0.001$ \\
\hline & ㅇ & 34 & 5.07 & 7 & 6.05 & 0.09 & 0.51 & 8.51 & & $<0.001$ \\
\hline \multirow[t]{2}{*}{ IND } & $0^{7}$ & 44 & 3.26 & 5.48 & 4.22 & 0.08 & 0.56 & 13.22 & 5.34 & $<0.001$ \\
\hline & ㅇ & 34 & 3.69 & 5.76 & 4.85 & 0.08 & 0.46 & 9.48 & & $<0.001$ \\
\hline \multirow[t]{2}{*}{ NED } & $0^{7}$ & 44 & 4.01 & 6.33 & 5.02 & 0.08 & 0.56 & 11.16 & 7.32 & $<0.001$ \\
\hline & q & 34 & 4.92 & 7.05 & 5.88 & 0.08 & 0.45 & 7.73 & & $<0.001$ \\
\hline \multirow[t]{2}{*}{ ARML } & $0^{7}$ & 44 & 9.93 & 15.62 & 12.46 & 0.19 & 1.25 & 10.06 & 6.1 & $<0.001$ \\
\hline & \% & 34 & 11.85 & 16.73 & 14.2 & 0.21 & 1.25 & 8.78 & & $<0.001$ \\
\hline \multirow[t]{2}{*}{ TiL } & $0^{7}$ & 44 & 24.7 & 37.72 & 30.53 & 0.49 & 3.26 & 10.68 & 6.43 & $<0.001$ \\
\hline & 웅 & 34 & 30.21 & 39.86 & 35.02 & 0.47 & 2.76 & 7.89 & & $<0.001$ \\
\hline \multirow[t]{2}{*}{$\mathrm{TaL}$} & $0^{\prime \prime}$ & 44 & 13.57 & 18.72 & 16.05 & 0.22 & 1.49 & 9.29 & 6.93 & $<0.001$ \\
\hline & 웅 & 34 & 15.66 & 20.65 & 18.34 & 0.24 & 1.39 & 7.57 & & $<0.001$ \\
\hline \multirow[t]{2}{*}{$\mathrm{MtL}$} & $0^{7}$ & 44 & 21.82 & 31.93 & 26.46 & 0.41 & 2.72 & 10.28 & 5.59 & $<0.001$ \\
\hline & 우 & 34 & 25.1 & 32.85 & 29.63 & 0.37 & 2.15 & 7.24 & & $<0.001$ \\
\hline
\end{tabular}

Furthermore, significant differences were found in means of all other variables, with females reaching larger measurements than males (Table 1). When all the morphometric variables were introduced in a nonparametric perMANOVA test, the comparison of sexes was not significant $(\mathrm{F}=0.349, \mathrm{P}=0.865)$.

The PCA of size-adjusted measurements showed a total of ten components, with $69.09 \%$ of the variance comprised by the first two components, with PC1 accounting for $54.14 \%$ and PC2 $14.95 \%$ of the total variation. The bi-dimensional projection of the first two components exhibited a substantial overlap of sexes (Fig. 4A). The loadings indicate that $\mathrm{PC} 1$ has a strong positive correlation with TiL (0.61) and MtL (0.58), and the lowest with ED, IND, END and IOD (Fig. 4B), whereas PC2 is moderately correlated with TaL (0.35) and ARML (0.33), while MtL stood out with a very strong negative correlation of -0.76 (Fig. 4C).

The dendrogram obtained, with hierarchical clustering, was a good representation of the data matrix given the obtained coefficient of cophenetic correlation (CCC $=0.74$ ) and showed a topology of females and males in congruence with PCA and perMANOVA analyses, determining the absence of morphometric, sexual shape dimorphism. However, the low bootstrap percentages $(<50 \%)$ do not indicate high support for most of the similarity relationships.

\section{Morphometric differentiation}

Since multivariate analyses performed previously did not reveal significant differences between sexes, we pooled males and females within each basin in subsequent analyses. When all the morphometric variables were analyzed through perMANOVA test, significant differences were found among the six hydrographic basins evaluated in this work $(\mathrm{F}=2.553, \mathrm{P}<0.05)$. The pairwise comparisons showed significant differences between Río Negro and Río de la Plata basins (Table 2).

The PCA of original measured variables (including SVL variable), showed a total of eleven components, with $96.4 \%$ of the variance comprised by the first two components, with PC1 accounting for 93.96\% and PC2 2.47\% of the total variation. The bi-dimensional projection of $\mathrm{PC} 1$ vs. PC2 showed the convex polygons grouping indi- 


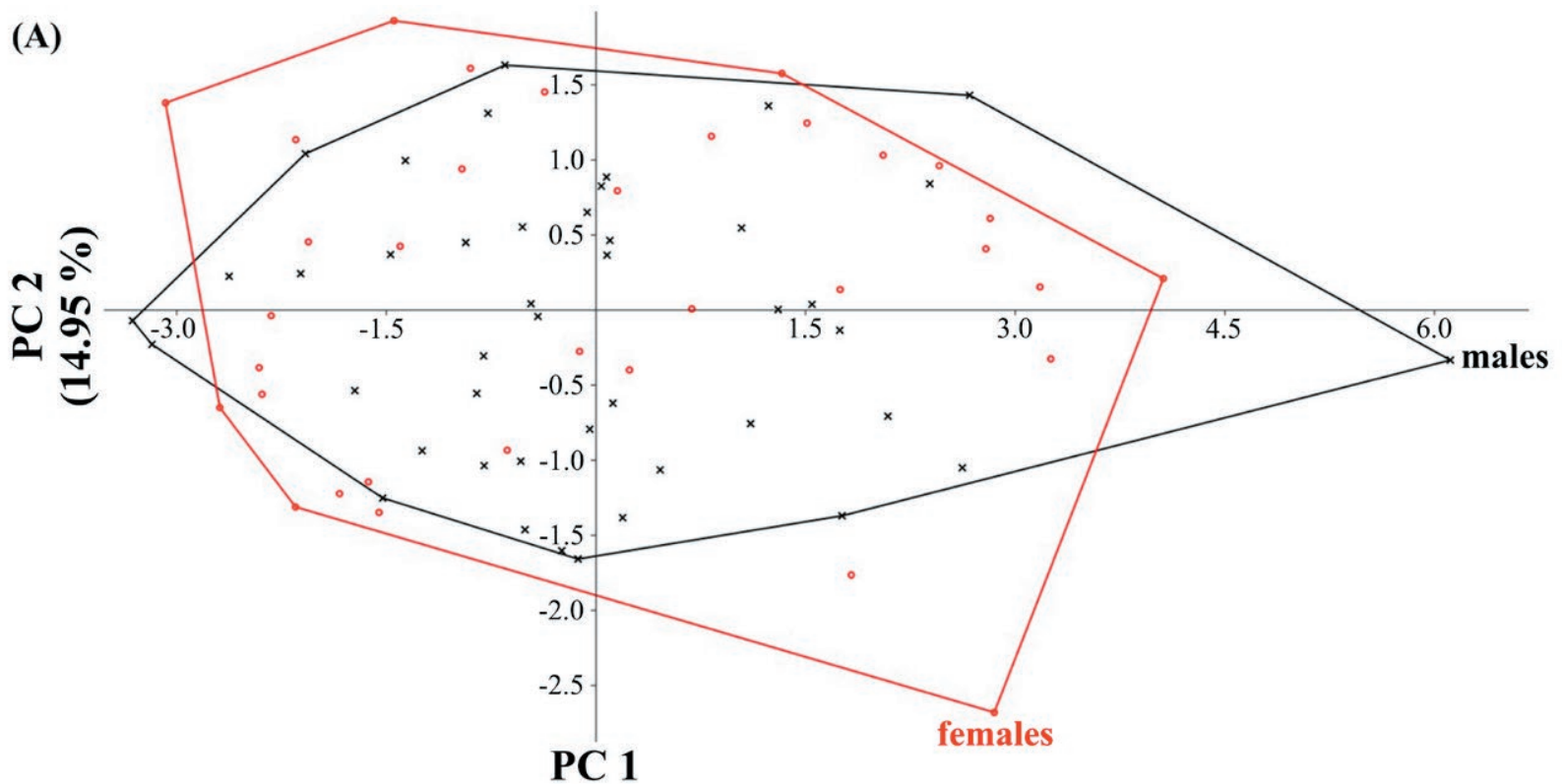

(B)

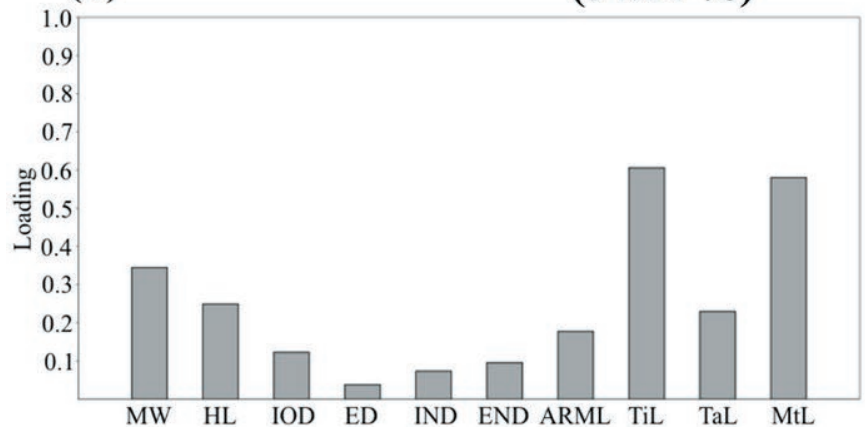

(C)

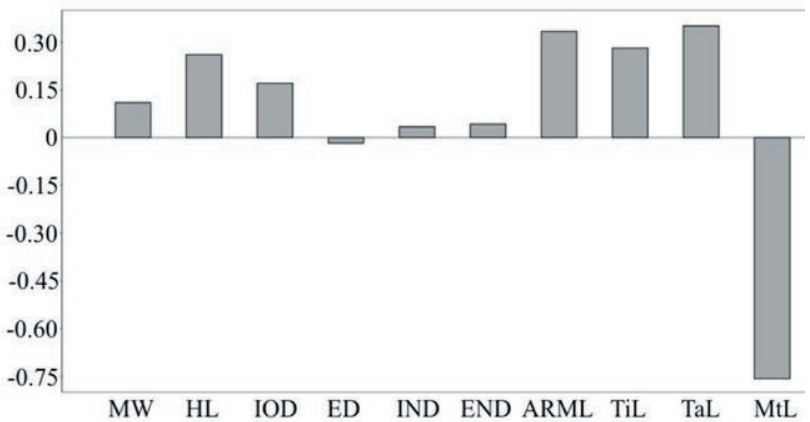

Fig. 4. (A) Scatter plot for the first two principal components obtained from a principal component analysis of eleven morphological variables measured in Limnomedusa macroglossa (Anura: Alsodidae) from Uruguay, including convex polygons grouping individuals according to their sex. Red circles represent females and black crosses are males. Coefficients of association of each morphometric variable with the first principal component (PC1) (B) and with the second principal component (PC2) (C). SVL = snout-vent length, MW = mandibular width; HL = head length; IOD = inter-orbital distance; ED = eye diameter; IND = inter-narial distance; END = eye-nostril distance; ARML $=$ arm length; $\mathrm{TiL}=$ tibia length; $\mathrm{TaL}=$ tarsus length and $\mathrm{MtL}=$ metatarsus length.

viduals from different basins with an elevated degree of overlap (Fig. 5A). According to Greene and Funk (2009), in PCA of morphological data, the first axis (PC1) is usually associated with size, and the remaining axes describe orthogonal axes of variation in shape. Indeed, we found that, the first axis has a strong positive correlation with body size and a moderate correlation with a few hind leg measurements: SVL (0.69), TiL (0.45) and MtL (0.33). Meanwhile, head measurements (IOD, ED, IND and END) showed the weakest correlation (Fig. 5B). The second axis (shape axis) has a strong positive correlation with $\mathrm{MtL}$ (0.56), and a moderate correlation with MW (0.32) and TiL (0.31), while SVL stood out with a strong negative correlation -0.67 (Fig. 5C).
Given the considerable contribution of SVL, TiL and MtL variables in size and shape axis of PCA, we did a box plot according to the hydrographic basins in order to show the differences between them. Significant differences were found between hind leg length of individuals from Río de la Plata and Río Negro basins $(t=3.533$, P $<0.001$ ), being those of Río de la Plata basin the longest hind leg $(82.12 \pm 2.21 \mathrm{~mm}, \mathrm{n}=12)$, while those of Río Negro basin were the shortest legs $(72.55 \pm 1.55 \mathrm{~mm}, \mathrm{n}=$ 25) (Fig. 6A,B), reaching a difference of $11,65 \%$. Regarding SVL, we found a similar pattern, reaching higher values in Río de la Plata basin $(56.31 \pm 1.57 \mathrm{~mm}, \mathrm{n}=12)$ and lower ones in Río Negro basin $(50.12 \pm 1.06 \mathrm{~mm}, \mathrm{n}$ $=25 ; \mathrm{t}=3.302, \mathrm{P}<0.002$; Fig. $7 \mathrm{~A}$ ), reaching a difference 
Table 2. One-way perMANOVA results for morphometric data of Limnomedusa macroglossa from Uruguay taking into account the six hydrographic basins evaluated in this work: Río Uruguay, Río Santa Lucía, Océano Atlántico, Laguna Merín, Río de la Plata and Río Negro. Bonferroni corrected $\mathrm{P}$ values are displayed. Basins for which significant differences were obtained are in bold.

\begin{tabular}{|c|c|c|c|c|c|}
\hline & Río Santa Lucía & Río Negro & Laguna Merín & Río de la Plata & Océano Atlántico \\
\hline Río Uruguay & 1 & 0.462 & 1 & 1 & 1 \\
\hline Río Santa Lucía & & 1 & 1 & 1 & 1 \\
\hline Río Negro & & & 1 & 0.024 & 1 \\
\hline Laguna Merín & & & & 1 & 1 \\
\hline Río de la Plata & & & & & 1 \\
\hline
\end{tabular}

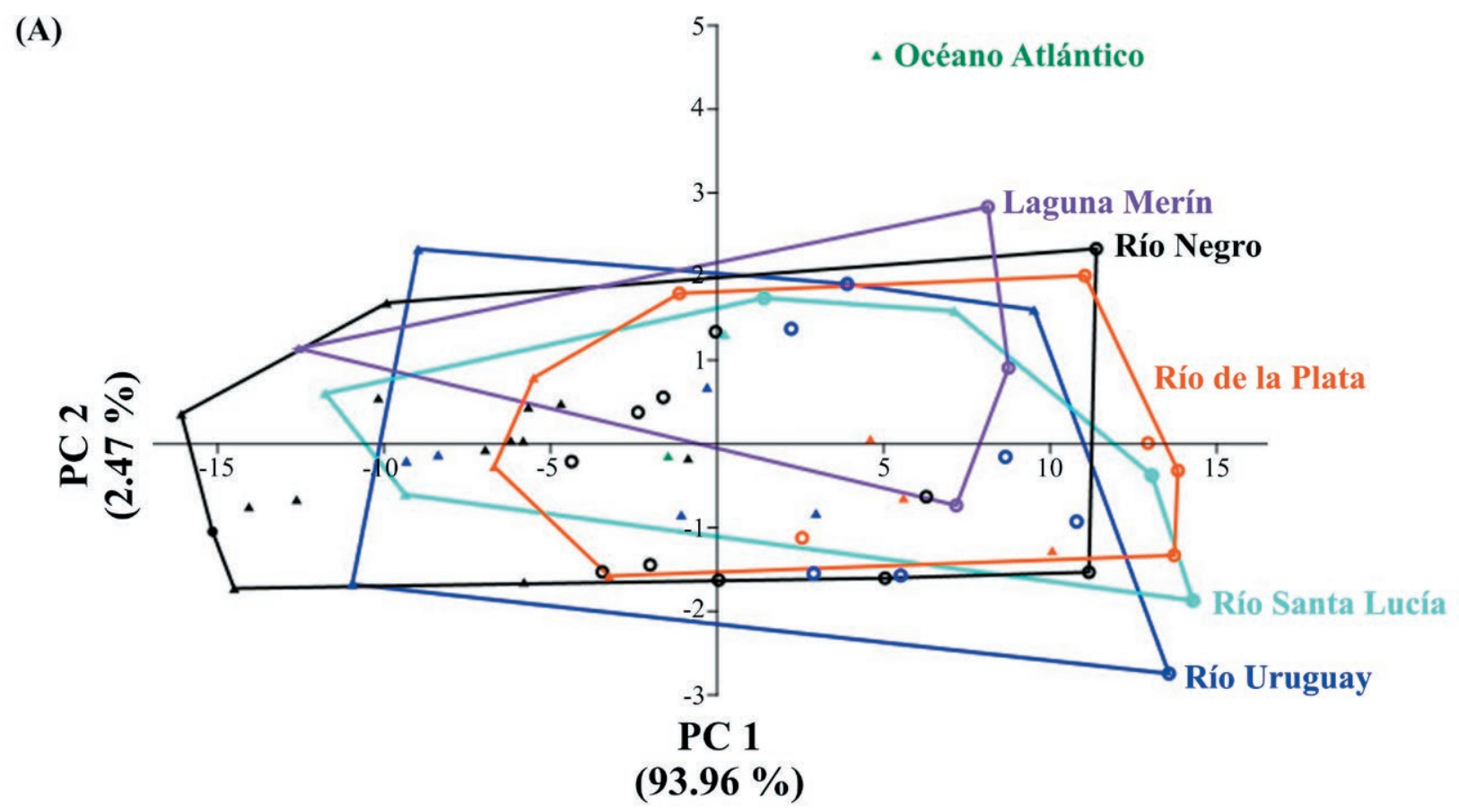

(B)

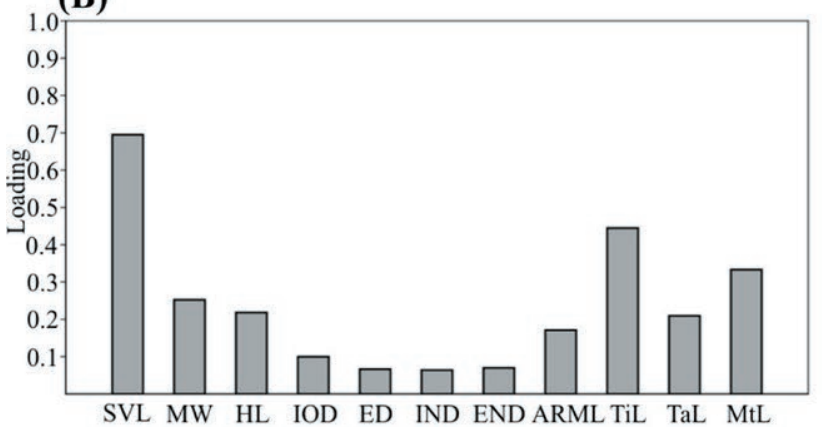

(C)

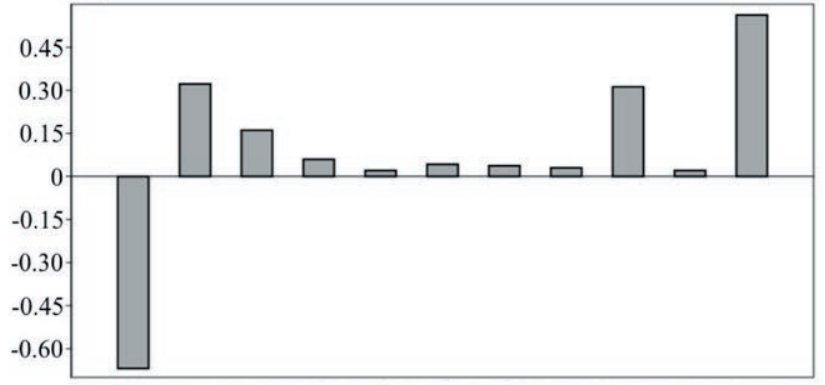

Fig. 5. (A) Scatter plot for the first two principal components obtained from a principal component analysis of eleven morphological variables measured in Limnomedusa macroglossa (Anura: Alsodidae) taking into account hydrographic basins from Uruguay, including convex polygons grouping individuals according to basins. Fill triangles represent males and circles are females. Basins: blue = Río Uruguay; sky blue $=$ Río Santa Lucía; green $=$ Océano Atlántico; violet $=$ Laguna Merín; orange $=$ Río de la Plata; black $=$ Río Negro . Coefficients of asso ciation of each morphometric variable with the first principal component (PC1) (B) and with the second principal component (PC2) (C) taking into account hydrographic basins from Uruguay. SVL = snout-vent length, MW = mandibular width; HL = head length; IOD = interorbital distance; $\mathrm{ED}=$ eye diameter; IND = inter-narial distance; END = eye-nostril distance; $\mathrm{ARML}=$ arm length; TiL = tibia length; TaL $=$ tarsus length and $\mathrm{MtL}=$ metatarsus length. 
(A)

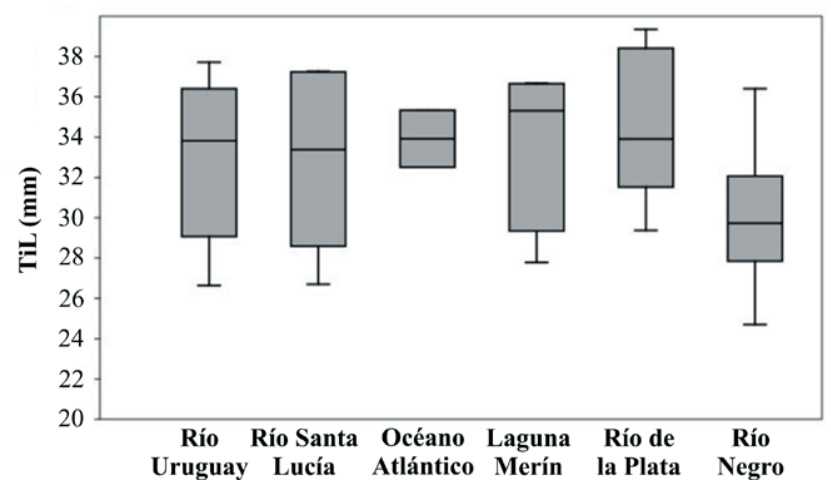

(B)

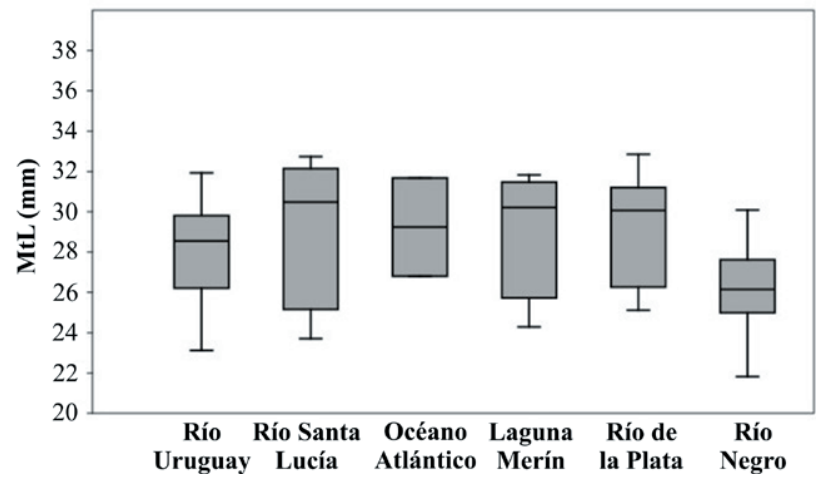

Fig. 6. Box plots of TiL (A) and MtL (B) variables of Limnomedusa macroglossa (Anura: Alsodidae) according to hydrographic basins from Uruguay, considering males and females grouped. $\mathrm{TiL}=$ tibia length and $\mathrm{MtL}=$ metatarsus length. The line inside de boxes represents the median. All measurements are in millimeters.

(A)

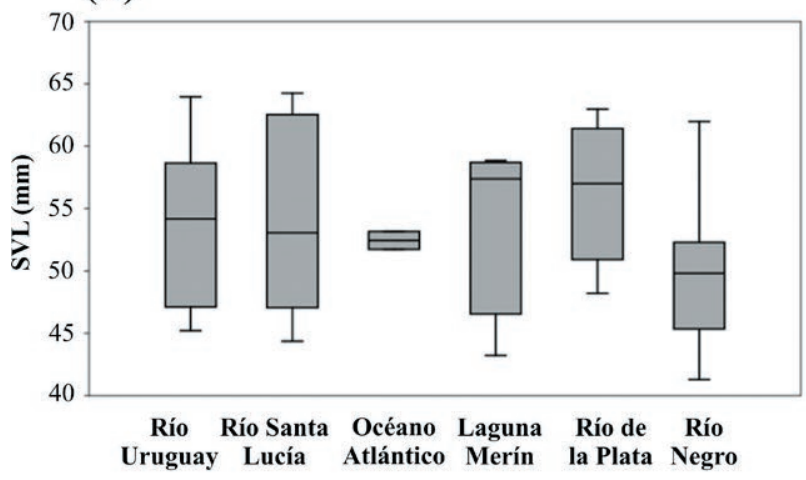

(B)

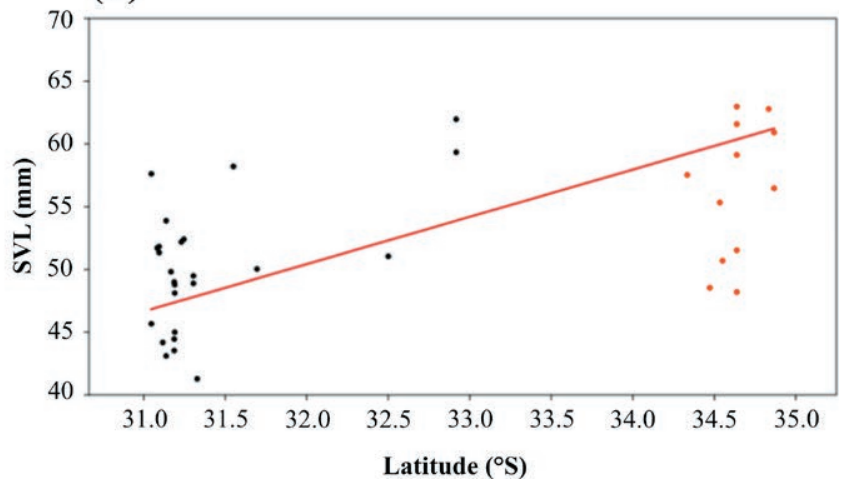

Fig. 7. (A) Box plot of body size (SVL) of Limnomedusa macroglossa (Anura: Alsodidae) according to hydrographic basins from Uruguay, considering males and females grouped. (B) Latitude-SVL relationship for L. macroglossa. The line represents the regression model. Red circles represent individuals of Río de la Plata basin and black circles are individuals of Río Negro basin. The line inside de boxes represents the median. SVL measurements are in millimeters.

of $11 \%$ between groups. Additionally, a significant correlation between latitude and SVL was found $(\mathrm{r}=0.60, \mathrm{~F}=$ 4.35, P < 0.001; Fig. 7B).

\section{Allometric regressions}

We performed a SMA analysis with the variables that showed the highest correlations with PC1 and PC2 in PC analyzes. We found a significant SMA relationship between SVL and MtL in females $[b=0.98,95 \%$ confidence interval $(\mathrm{CI})=0.78-1.23]$ and males $[\mathrm{b}=1.09,95 \%$ $\mathrm{CI}=0.94-1.25]$. It was also significant between SVL and TiL in females $[\mathrm{b}=1.06,95 \% \mathrm{CI}=0.88-1.27]$ and males $[\mathrm{b}=1.13,95 \% \mathrm{CI}=1.02-1.25]$ and between SVL and MW in females $[b=0.93,95 \% \mathrm{CI}=0.75-1.16]$ and males $[b=1.03,95 \% \mathrm{CI}=0.90-1.18]$. In males, the SVL vs. TiL relationship showed a significant positive allometry $(b=1.128)$. On the other hand, in all the other cases, there were no significant differences from isometry (Table 3).

In all cases, the test for common slope across sexes indicated that there are no significant differences in common slope between males and females. When testing for shifts along the common slope, we found significant shifts in all relationships with higher values in females (SVL-MtL relationship: $\mathrm{W}=42.952, \mathrm{P}<0.01$; SVL-TiL relationship: $\mathrm{W}=47.729, \mathrm{p}<0.01)$. The test for shift in elevation was only significant in the SVL vs. MtL relationship in favor of males ( $\mathrm{W}=4.411, \mathrm{P}<0.05)$, but the difference in elevation was rather small and close to our resolution limit $(0.01 \mathrm{~mm})$. 
Table 3. Standarized major axis (SMA) regression results and test of isometry for Limnomedusa macroglossa. Variables used in analyses were: $\mathrm{SVL}=$ snout-vent length; $\mathrm{TiL}=$ tibia length and $\mathrm{MtL}=$ metatarsus length. Abbreviations: $a=$ intercept. Significant regressions are in bold.

\begin{tabular}{lccccc}
\hline \multirow{2}{*}{ Variables } & \multicolumn{3}{c}{ SMA regression } & \multicolumn{3}{c}{ Test of isometry } \\
\cline { 2 - 6 } & $a$ & $\mathrm{r}^{2}$ & $p$ & $\mathrm{~F}$ & $p$ \\
\hline log MtL vs. log SVL & & & & & \\
Females & -0.2471 & 0.575 & $<\mathbf{0 . 0 1}$ & 0.034 & 0.855 \\
Males & -0.4193 & 0.800 & $<\mathbf{0 . 0 1}$ & 1.422 & 0.240 \\
\hline log TiL vs. log SVL & & & & & \\
Females & -0.3117 & 0.733 & $<\mathbf{0 . 0 1}$ & 0.370 & 0.548 \\
Males & -0.4295 & 0.891 & $<\mathbf{0 . 0 1}$ & 5.620 & $\mathbf{0 . 0 2}$ \\
\hline
\end{tabular}

\section{DISCUSSION}

In this study we determined the minimum size at sexual maturity (MSSM) and described morphometric and intersexual differences in Limnomedusa macroglossa. We showed that females and males differ in MSSM, presence of dark nuptial pads in males (a sexually dimorphic characteristic) and body size, while no differences were found in body shape. Nuptial pads can be observed during the breeding season in response to increases in circulating levels of androgens, but later regress during the non-breeding period, although without resembling to a female-like morphology (Wells, 2007). Some authors argued that well-developed nuptial pads are associated with breeding in water to prevent the female's escape during amplexus (Duellman and Trueb, 1986). However, according to Savage (1961), nuptial pads also allow the male to hold the female while defending her against rival males.

The MSSM is the size at which an individual has all the morphological and physiological conditions to begin to breed, and along with sexual dimorphism, are important life history traits to understand population changes through time. Life history theory explains the variation in MSSM between sexes through natural selection mechanisms, mainly related with adult mortality rates (Tolosa et al., 2014). We found that females of Limnomedusa macroglossa reach sexual maturity around $49.82 \mathrm{~mm}$, while males reach it at a smaller size of about $41.29 \mathrm{~mm}$. This difference between the sexes can be explained by sexual selection: selection for mating effort in males to defend territories, in detriment of larger males due to the high energetic expenditures and risks of mortality, and parental effort in females to produce more eggs to maximize their reproductive output, which favors females with a larger size; both processes have been pointed out as potential explanations for sexual maturation at different ages (Howard, 1981).

There was sexual dimorphism in size in Limnomedusa macroglossa with females being larger than males, as it occurs in more than $90 \%$ of anurans species (Shine, 1979). These results agree with those found in a population of L. macroglossa in southern Brazil based on SVL only (Kaefer et al., 2009). Taking into account the main hypotheses regarding the causes of sexual dimorphism in anurans, natural and/or sexual selection might adequately explain the differences in body sizes between females and males found in this work. Given the available data until date (Kaefer et al., 2009; de Olivera et al., 2018) and our results, it seems that the preference for larger females evolved because they produce more oocytes per clutch (Bionda et al., 2011) or bigger eggs (the fecundity advantage hypothesis), whereas in males, natural selection works against of bigger body sizes due to the existence of possible differential predation, since the long reproductive period exposes and makes them more vulnerable to predators (Camargo et al., 2008). Furthermore, intra/intersexual selection could be playing an important role in the differentiation between males and females, through malemale competition and/or female choice (Darwin, 1871; Shine, 1979; Woolbright, 1983; Arak, 1988). Although, in our field work, we did not observe such behaviors, we cannot rule out their existence, since it has been reported that its a species with a prolonged reproduction pattern (Kaefer et al., 2009; de Olivera et al., 2018) which is usually associated with more territorial males, choosy females, and overall higher levels of sexual selection (Wells, 2007). Finally, the age structure in the reproductive populations may also be operating between sexes (Halliday and Verrell, 1986; Monnet and Cherry, 2002). Thus, the sexual dimorphism in size found in L. macroglossa could be the result of distinct, possibly opposing, selective forces that trade-off differently in each sex.

In addition to size, anurans exhibit other forms of sexual dimorphism, including: the proportions and muscular development of the forelimbs (related with clasping behavior), skin color, texture and glands (visual, tactile and chemical cues for sex recognition), fangs and tusks (related with combat), abdominal and laryngeal muscles, and lung capacities (calling behavior) (Wells, 2007; Bell and Zamudio, 2012) and head morphology (feeding strategies) (Khoshnamvand et al., 2018).

No differences were found in shape between sexes, but significant differences were found among basins. Some variables related with the hind legs showed the highest contributions to overall shape differentiation. A functional interpretation of the differentiation in the hindlimb length found in L. macroglossa could be that 
leg proportions may influence locomotor performance. Several experimental studies have shown how longer hindlimbs may improved locomotor performance (Orizaola and Laurila, 2009; Drakulic et al., 2016; ZamoraCamacho, 2018; Zamora-Camacho and Aragón, 2019), as well as jumping distance increases as the individual grows larger (Zug, 1978). Meanwhile, other studies revealed that locomotor performance is negatively affected at larger sizes (Moreno-Rueda et al., 2020), relatively large differences $(>10 \%)$ in leg length can affect the jumping efficiency (Emerson, 1978; Babik and Rafinski, 2000). Differences in jumping ability could be occurring in L. macroglossa because our results showed differences greater than $10 \%$ in body size and leg length in individuals from Río de la Plata basin compared to those from the Río Negro basin.

Alternatively, differences in the hindlimb length may be the result of unequal growth and developmental rate during the larval and juvenile stages (Emerson et al., 1988; Babik and Rafinski, 2000). Because amphibians are ectotherms and depend on water, they show phenotypic responses to changes in environmental factors. In this sense, some phenotypic plasticity can be attributed to environmental factors such as the duration of the larval period and its relation to size as a function of temperature (Vences et al., 2002). A general TemperatureSize rule for ectotherms states that higher temperatures increase developmental rates, at the cost of smaller size (Drakulic et al., 2016) and conversely, at low temperatures develop more slowly, so they metamorphose at larger body sizes (Harkey and Semlitsch, 1988). Moreover, some studies replace the idea of temperature and relate body size to latitude, predicting that body size within species increases with latitude (Lindsey, 1966; Schäuble, 2004). In this study we found that individuals which had the longest legs were from Río de la Plata basin, which correlates with the colder climate in the studied distribution (InUMet, 2020). On the other hand, the individuals which had shortest legs were found in Río Negro basin, where the temperature is significantly higher (InUMet, 2020). So, we can expect that differences in environmental temperature during the larval period may have been responsible for the variation in the hindlimbs length in L. macroglossa. This trend has already been reported in other studies (Atkinson, 1994, 1995; Angilletta et al., 2004). Furthermore, our results are consistent with the intraspecific version of Bergmann's rule. It relates to geographic variation in the body sizes of animals (Blackburn et al., 1999) which has been briefly stated by Mayr as: The smaller-sized geographic races of a species are found in the warmer parts of the range, the larger-sized races in the cooler districts (Ray, 1960).
In this study we report a clinal variation in the relative leg length and body size of Limnomedusa macroglos$s a$ along a latitudinal gradient in Uruguay. The body size dimorphism likely reflects differences in growth rates of males and females. In organisms with indeterminate growth, body size is a result of a trade-off between growth and reproduction (Camargo et al., 2008). Therefore, females of Limnomedusa macroglossa appear to delay sexual maturity, while maintaining the same body shape and proportions as the males, reaching larger sizes at maturity, based on the combined evidence of distinct MSSM and the body size shift along the common isometric slopes of males and females. This difference in size could be adaptive for females, since a larger body size would increase the volume of the abdominal cavity, being able to accommodate larger ovaries (de Olivera et al., 2018) and consequently, increasing their reproductive output [the so called fecundity advantage hypothesis (Darwin, 1871)]. Therefore, sexual dimorphism in $L$. macroglossa could be determined by differential growth rate between the sexes, since the growth rates are usually asymptotic after maturation and sexes generally mature at different ages (sexual bimaturity) (Monnet and Cherry, 2002; Kupfer, 2007; Wells, 2007), or it may be the result of difference in the age distributions of males and females (Howard, 1981). Therefore, the sexual dimorphism found in body size is probably the consequence of higher growth rates and/or late sexual maturity in females of Limnomedusa macroglossa, which favors a larger body size and larger ovaries, and consequently, higher reproductive output.

\section{CONCLUSIONS}

In conclusion, our data on MSSM and SSD of Limnomedusa macroglossa from Uruguay may contribute to the knowledge of the life history traits of this species.

Our results show that females attained sexual maturity at larger sizes than males with a marked female biased sexual size dimorphism. These traits are driven by a tradeoff between natural and sexual selection on each sex: parental effort in females does favor larger sizes to maximize their reproductive output, because bigger females can accommodate more eggs in their abdominal cavity. Meanwhile, mating effort in males does not favor large sizes due to energetic expenditures and risk of mortality during the long breading season, because bigger males invest most of their energy in search and calling behavior and have high mortality rates due to predation risk.

We also report a clinal variation in the relative leg length and body size of Limnomedusa macroglossa along 
a latitudinal gradient in Uruguay. Individuals with longest legs and bigger body sizes were from Río de la Plata basin, meanwhile individuals with shortest legs and smaller body sizes were those found in Río Negro basin. These differences could be explained by phenotypic plasticity in age and size at metamorphosis when separate populations are exposed to different environmental conditions (Ruthsatz et al., 2018). Studies demonstrated a plastic response of metamorphic traits in anuran larvae to changes in environmental conditions such as temperature. With increasing temperature time to metamorphosis may be reduced and metamorphosis occurs at smaller body sizes (Vences et al., 2002). Then, this may be occurring in L. macroglossa, since Río de la Plata basin is correlated with the colder climate in the studied distribution, meanwhile Río Negro basin is correlated with a warmer one.

All the evidence gathered in this work and its interpretations show that sexual dimorphism found in body size is likely the consequence of higher growth rates and/or late sexual maturity in females of Limnomedusa macroglossa, which favors a larger body size and bigger ovaries, and consequently, higher reproductive output. Examination of adult females and males, already in progress, will soon allow a more in depth understanding of L. macroglossa reproductive biology in Uruguay.

\section{ACKNOWLEDGEMENTS}

We thank Ernesto Elgue and Claudia Fernández for his help in fieldwork and Pablo Toriño for drawings and statistical support. This work was supported by Comisión Sectorial de Investigación Científica under Grant CSIC I+D 2012 from University of the Republic. All animals have been captured, handled and euthanized in accordance with relevant guidelines in full compliance with specific permits released by the Institutional Animal Care and Use Committee (IACUC) of the Faculty of Sciences, University of the Republic; the Honorary Committee for Animal Experimentation (CHEA) regulated in the National Law of Animal Experimentation $\mathrm{N}^{\circ} 18611$ (Oct. 2, 2009); the Ordinance on the Use of Animals in Experimentation, Teaching and University research (C.D.C. Res. No11 Dec. 21,1999, University of the Republic) and the corresponding scientific collection permit issued by the Ministry of Livestock, Agriculture and Fisheries of Uruguay (MGAP) (Res. 126/14).

We thank two anonymous reviewers and the associate editor that provided comments and suggestions for improving an earlier version of the manuscript.

\section{REFERENCES}

Achkar, M., Domínguez, A., Pesce, F. (2013): Cuencas hidrográficas del Uruguay: situación y perspectivas ambientales y territoriales. Redes Amigos de la Tierra, Montevideo.

Angilletta, M. Jr., Steury, T., Sears, M. (2004) : Temperature, Growth Rate, and Body Size in Ectotherms : Fitting Pieces of a Life-History Puzzle. Integr. Comp. Biol. 44: 498-509.

Arak, A. (1988): Sexual size dimorphism in body size: a model and a test. Evol. 42: 820-825.

Atkinson, D. (1994): Temperature and Organism Size A Biological Law for Ectotherms? Adv. Ecol. Res. 25: $1-58$.

Atkinson, D. (1995): Effects of Temperature on the size of Aquatic Ectotherms: Exceptions to the General Rule. J. Therm. Biol. 20: 61-74.

Babik, W., Rafinski, J. (2000). Morphometric differentiation of the moor frog (Rana arvalis Nilss.) in Central Europe. J. Zool. Syst. Evol. Res. 38: 239-247.

Baraquet, M., Grenat, P.R., Salas, N.E., Martino, A.L. (2012): Variación morfométrica y geográfica entre poblaciones de Hypsiboas cordobae (Anura: Hylidae) en Argentina. Cuad. Invest. UNED. 4: 147-155.

Bell, R.C., Zamudio, K.R. (2012): Sexual dichromatism in frogs: natural selection, sexual selection and unexpected diversity. Proc. R. Soc. B. 279: 1-7.

Bionda, C., Lajmanovich, R., Salas, N., Martino, A., Di Tada, I. (2011): Reproductive ecology of the common south american toad Rhinella arenarum (Anura: Bufonidae): Reproductive effort, clutch size, fecundity, and mate selection. J. Herpetol. 45: 261-264.

Blackburn, T., Gaston, K., Loder, N. (1999): Geographic gradients in body size: A Clarification of Bergmann's rule. Div. Distrib. 5: 165-174.

Camargo, A., Sarroca, M., Maneyro, R. (2008): Reproductive effort and the egg number vs. size trade-off in Physalaemus frogs (Anura: Leiuperidae). Acta Oecol. 34: 163-171.

Castellano, S., Giacoma, C., Dujsebayeva, T. (2000): Morphometric and advertisement call geographic variation in polyploid green toads. Biol. J. Linnean Soc. 70: 341-360.

Darwin, C.R. (1871): The descent of man and selection in relation to sex. John Murray, London.

de Olivera, V., Camargo, A., Maneyro, R. (2018): Biología reproductiva de Limnomedusa macroglossa (Duméril \& Bibron, 1841) (Anura: Alsodidae) en Uruguay. In: Book of abstracts V Congreso Uruguayo de Zoología, pp. 78. Sociedad Zoológica del Uruguay Eds, Montevideo. 
Drakulic, S., Feldhaar, H., Lisicic, D., Mioc, M., Cizelj, I., Seiler, M., Spatz, T., Rodel, M-O. (2016): Populationspecific effects of developmental temperature on body condition and jumping performance of a widespread European frog. Ecol. Evol. 6: 3115-3128.

Duellman, W.E. (1970): The Hylid frogs of Middle America. Museum of Natural History, University of Kansas.

Duellman, W. E., Trueb. L. (1986): Biology of amphibians. McGraw-Hill, New York.

Emerson, S.B. (1978): Allometry and jumping in frogs: helping the twain to meet. Evol. 32: 551-564.

Emerson, S.B., Travis, J., Blouin, M. (1988): Evaluating a hypothesis about heterochrony: larval life-history traits and juvenile hind-limb morphology in Hyla crucifer. Evol. 42: 68-78.

Fairbairn, D.J. (1997): Allometry for sexual size dimorphism: Pattern and process in the coevolution of body size in males and females. Annu. Rev. Ecol. Syst. 28: 659-687.

Falster, D.S., Warton, D.I., Wright, I.J. (2006): User's guide to SMATR: Standardised Major Axis Tests and Routines. Available from: http://bio.mq.edu.au/research/ groups/comparative/SMATR/SMATR_users_guide.pdf

Fathinia, B., Rastegar-Pouyani, N., Darvishnia, H., Mohamadi, H., Faizi, H. (2012): Sexual size dimorphism in Rana (Pelophylax) ridibunda ridibunda Pallas, 1771 from a population in Darre-Shahr Township, Ilam Province, western Iran. Amphib. Reptile Conserv. 5: 92-97.

Fernández, C. (2016.): Diversidad filogeográfica a múltiple escala en poblaciones de Limnomedusa macroglossa (Anura, Alsodidae) de Uruguay. Master's Thesis. Universidad de la República, Facultad de Ciencias, Montevideo. Only available online at: https://www. colibri.udelar.edu.uy/jspui/handle/20.500.12008/8438

Frost, D.R. (2020): Amphibian Species of the World 6.0, an Online Reference. [Internet]. New York: American Museum of Natural History. Available from: https:// amphibiansoftheworld.amnh.org/index.php

Frost, D.R., Grant, T., Faivovich, J., Bain, R.H., Haas, A., Haddad, C.F.B., de Sá, R.O., Channing, A., Wilkinson, M., Donnellan, S.C., Raxworthy, C.J., Campbell, J.A., Blotto, B.L., Moler, P., Drewes, R.C., Nussbaum, R.A., Lynch, J.D., Green, D.M., Wheeler, W.C. (2006): The amphibian tree of life. Bull. Am. Mus. Nat. Hist. 297: 1-370.

Green, D.M. (2015): Implications of female body-size variation for the reproductive ecology of an anuran amphibian. Ethol. Ecol. Evol. 27: 173-184.

Greene, A.E., Funk, W.C. (2009): Sexual selection on morphology in an explosive breeding amphibian, the Columbia spotted frog (Rana luteiventris). J. Herpetol. 43: 244-251.
Grenat, P.R., Salas, N.E., Martino, A.L. (2012): Intra- and inter-specific morphometric variation between Odontophrynus populations (Anura: Cycloramphidae) of central Argentina. Int. J. Trop. Biol. 60: 1589-1601.

Gudynas, E., Gehrau, A. (1981): Notas sobre la distribuición y ecología de Limnomedusa macroglossa (Dumeril \& Bibron, 1841) en Uruguay (Anura, Leptodactylidae). Iheringia Ser. Zool. 60: 81-99.

Halliday, T.R., Verrell, P.A. (1986): Review: Sexual selection and body size in amphibians. Herpetol. J. 1: 86-92.

Hammer, Ø., Harper, D.A.T., Ryan, P.D. (2001): PAST: Paleontological statistics software package for education and data analysis. Palaeontol. Electron. 4: 1-9.

Harkey, G.A., Semlitsch, R.D. (1988): Effects of temperature on growth, development, and color polymorphism in the ornate chorus frog Pseudacris ornata. Copeia 1988: 1001-1007.

Hartmann, D. (2016): Global Physical Climatology. Elsevier Science. University of Washington, Washington.

Howard, R.D. (1981): Sexual dimorphism in bullfrogs. Ecology 62: 303-310.

InUMet. (2020): Climatología del Verano (dic-ene-feb) en Uruguay 1981-2010. Instituto Uruguayo de Meteorología. Only available online at: https://www.inumet.gub.uy/sites/default/files/2020-12/CLIMATOLOGIA\%20DEL\%20VERANO_LQ_0.pdf

Kaefer, I.L., Both, C., Zanini Cechin, S. (2009): Breeding biology of the rapids frog Limnomedusa macroglossa (Anura: Cycloramphidae) in southern Brazil. J. Nat. Hist. 43: 1195-1206.

Kaliontzopoulou, A. (2011): Geometric morphometrics in herpetology: modern tools for enhancing the study of morphological variation in amphibians and reptiles. Basic Appl. Herpetol. 25: 5-32.

Khoshnamvand, H., Malekian, M., Keivany, Y. (2018): Morphological distinction and sexual dimorphism in divergent clades of Neurergus kaiseri (Amphibia: Salamandridae). Basic Appl. Herpetol. 32: 5-17.

Kupfer, A. (2007): Sexual size dimorphism in amphibians: an overview. In: Sex, size and gender roles: evolutionary studies of sexual size dimorphism, pp. 50 59. Fairbairn, D.J., Blanckenhorn, W., Székely, T. Eds. Oxford University Press, Oxford.

Lindsey, C.C. (1966): Body sizes of poikilotherm vertebrates at different latitudes. Evol. 20: 456-465.

Lleonart, J., Salat, J., Torres, G.J. (2000): Removing allometric effects of body size in morphological analisys. J. Theor. Biol. 205: 85-93.

Lovich, J., Gibbons, J. (1992): A review of Techniques for Quantifying Sexual Size Dimorphism. Growth Dev. Aging. 56: 269-281. 
Maneyro, R., Carreira, S. (2012): Guía de Anfibios del Uruguay. Ediciones de la fuga, Montevideo.

Maneyro, R., Langone, J., Carreira, S. (2019): Anfibios. In: Libro Rojo de los Anfibios y Reptiles del Uruguay. Biología y conservación de los Anfibios y Reptiles en peligro de extinción a nivel nacional, pp. 17-106. Carreira, S., Maneyro, R. Eds. Montevideo.

Monnet, J-M., Cherry, M.I. (2002): Sexual size dimorphism in anurans. Proc. R. Soc. Lond. B. 269: 23012307.

Moreno-Rueda, G., Requena-Blanco, A., Zamora-Camacho, F., Comas, M., Pascual, G. (2020): Morphological determinants of jumping performance in the Iberian green frog. Curr. Zool. 66: 417-424.

Nali, R.C., Zamudio, K.R., Haddad, C.F.B., Prado, C.P.A. (2014): Size-dependent selective mechanisms on males and females and the evolution of sexual size dimorphism in frogs. Am. Nat. 184: 1-14.

Napoli, M.F. (2005): A new species allied to Hyla circumdata (anura: hylidae) from Serra da Mantiqueira, southeastern Brazil. Herpetologica. 61: 63-69.

Orizaola, G., Laurila, A. (2009): Microgeographic variation in the effects of larval temperature environment on juvenile morphology and locomotion in the pool frog. J. Zool. 277: 267-274.

Pyron, R.A., Wiens, J.J. (2011): A large-scale phylogeny of amphibia including over 2800 species, and a revised classification of extant frogs, salamanders, and caecilians. Mol. Phylogenet. Evol. 61: 543-583.

QGIS Development Team. (2016): QGIS Quantum Geographic Information System. Open Source Geospatial Foundation Project. Available from: https://issues.qgis. org/projects/qgis/wiki/QGIS_Citation_Repository

Ray, C. (1960): The Application of Bergmann's and Allen's Rules to the Poikilotherms. J. Morphol. 106: 85-108.

Rohlf, F.J. (1990): Morphometrics. Annu. Rev. Ecol. Syst. 21: 299-316.

Ruthsatz, K., Peck, M., Dausmann, K., Sabatina, N., Glos, J. (2018): Patterns of temperature induced developmental plasticity in anuran larvae. J. Therm. Biol. 74: 123-132.

Savage, R.M. (1961): The ecology and life history of the common frog. Sir Isaac Pitman and Sons, London.

Schäuble, C.S. (2004): Variation in body size and sexual dimorphism across geographical and environmental space in the frogs Limnodynastes tasmaniensis and $L$. Peronii. Biol. J. Linn. Soc. Lond. 82: 39-56.

Shine, A. (1979): Sexual selection and sexual dimorphism in the Amphibia. Copeia 1979: 297-306.

The Gnome Project. (2018): The Gnumeric Spreadsheet: Free, Fast, Accurate --- pick any three. Available from: http://www.gnumeric.org/
Silvano, D., Garcia, P., Kwet, A., Segalla, M.V., Langone, J., Baldo, D. (2004): Limnomedusa macroglossa. The IUCN Red List of Threatened Species. Available from: dx.doi.org/10.2305/IUCN.UK.2004.RLTS. T57176A11580028.en

Tolosa, Y., Molina-Zuluaga, C., Restrepo, A., Daza, J. (2014): Sexual maturity and sexual dimorphism in a population of the rocket-frog Colostethus aff. fraterdanieli (Anura: Dendrobatidae) on the northeastern Cordillera Central of Colombia. Actual. Biol. 37: 287294.

Vences, M., Puente, M., Nieto, S., Vieites, D.R. (2002): Phenotypic plasticity of anuran larvae: environmental variables influence body shape and oral morphology in Rana temporaria tadpoles. J. Zool. 257: 155-162.

Warton, D.I., Wright, I.J., Falster, D.S., Westoby, M. (2006): Bivariate line-fitting methods for allometry. Biol. Rev. 81: 259-291.

Wells, K.D. (2007): The ecology and behaviour of amphibians. University of Chicago Press, Chicago.

Woolbright, L.L. (1983): Sexual selection and size dimorphism in anuran Amphibia. Am. Nat. 121: 110-119.

Zamora-Camacho, F. (2018): Locomotor performance in a running toad: roles of morphology, sex and agrosystem versus natural habitat. Biol. J. Linn. Soc. 123: 411-421.

Zamora-Camacho, F., Aragón, P. (2019): Failed predator attacks have detrimental effects on antipredatory capabilities through developmental plasticity in Pelobates cultripes toads. Funct. Ecol. 33: 846-854.

Zug, G.R. (1978): Anuran locomotion-structure and function, 2: jumping performance of semiaquatic, terrestrial, and arboreal frogs. Smithsonian Institution Press, Washington.

\section{APPENDIX 1}

Six hydrographic basins of Uruguay and its geographic location (based on Achkar et al., 2013).

\begin{tabular}{lcc}
\hline Basins & Latitude $(\mathrm{S})$ & Longitude $(\mathrm{W})$ \\
\hline Río Uruguay & $30^{\circ} 5^{\prime} 10^{\prime \prime}-33^{\circ} 54^{\prime} 59^{\prime \prime}$ & $55^{\circ} 48^{\prime} 45^{\prime \prime}-58^{\circ} 26^{\prime} 17^{\prime \prime}$ \\
Río Santa Lucía & $33^{\circ} 42^{\prime} 1^{\prime \prime}-34^{\circ} 50^{\prime} 24^{\prime \prime}$ & $54^{\circ} 59^{\prime} 24^{\prime \prime}-57^{\circ} 07^{\prime} 11^{\prime \prime}$ \\
Océano Atlántico & $33^{\circ} 39^{\prime} 56^{\prime \prime}-34^{\circ} 58^{\prime} 26^{\prime \prime}$ & $53^{\circ} 22^{\prime} 13^{\prime \prime}-55^{\circ} 10^{\prime} 8^{\prime \prime}$ \\
Laguna Merín & $31^{\circ} 54^{\prime} 18^{\prime \prime}-34^{\circ} 24^{\prime} 51^{\prime \prime}$ & $53^{\circ} 02^{\prime} 27^{\prime \prime}-55^{\circ} 22^{\prime} 10^{\prime \prime}$ \\
Río de la Plata & $33^{\circ} 52^{\prime} 17^{\prime \prime}-34^{\circ} 58^{\prime} 26^{\prime \prime}$ & $54^{\circ} 55^{\prime} 14^{\prime \prime}-58^{\circ} 24^{\prime} 47^{\prime \prime}$ \\
Río Negro & $30^{\circ} 49^{\prime} 59^{\prime \prime}-33^{\circ} 57^{\prime} 37^{\prime \prime}$ & $54^{\circ} 9^{\prime} 42^{\prime \prime}-58^{\circ} 25^{\prime} 7^{\prime \prime}$ \\
\hline
\end{tabular}




\section{APPENDIX 2}

Thirty four mature females (\$) of Limnomedusa macroglossa used in the analyses and their respective morphometric measurements, basin and latitude/longitude from Uruguay. ZVC-B: vertebrate collection of the Faculty of Sciences, University of the Republic. SVL: snout-vent length; MW: mandibular width; HL: head length; IOD: inter-orbital distance; ED: eye diameter; IND: inter-narial distance; END: eye-nostril distance; ARML: arm length; TiL: tibia length; TaL: tarsus length; MtL: metatarsus length.

\begin{tabular}{|c|c|c|c|c|c|c|c|c|c|c|c|c|c|c|}
\hline $\begin{array}{l}\text { ACRONYM } \\
\text { (Adult }+ \text { ) }\end{array}$ & SVL & MW & $\mathrm{HL}$ & IOD & ED & IND & END & ARML & TiL & $\mathrm{TaL}$ & $\mathrm{MtL}$ & Basin & Latitude & Longitude \\
\hline 12 & 60.95 & 23.98 & 20.47 & 10.75 & 7 & 5.76 & 5.88 & 14.2 & 37.59 & 18.73 & 29.81 & Río Uruguay & -30.1166667 & -57.05 \\
\hline 24 & 53.06 & 21.3 & 18.27 & 8.39 & 5.49 & 4.77 & 5.76 & 13.05 & 32.81 & 17.59 & 30.48 & Río Santa Lucía & -34.0666667 & -56.8833333 \\
\hline 127 & 58.88 & 23.21 & 20.53 & 9.22 & 5.95 & 5.06 & 6.09 & 14.32 & 36.41 & 19.58 & 30 & Río Uruguay & -30.75 & -56.3333333 \\
\hline 32 & 56.15 & 21.17 & 18.02 & 8.66 & 6 & 4.76 & 5.75 & 14.34 & 32.44 & 17.4 & 28.55 & Río Uruguay & -30.75 & -56.3333333 \\
\hline 33 & 54.11 & 20.13 & 17.73 & 8.62 & 5.36 & 4.29 & 5.91 & 12.99 & 35.53 & 17.54 & 32.12 & - & - & - \\
\hline 51 & 61.97 & 22.3 & 20.19 & 8.93 & 6.79 & 5.09 & 6.36 & 14.05 & 36.41 & 19.83 & 31.83 & Río Negro & -32.9166667 & -54.9333333 \\
\hline 53 & 56.55 & 24.12 & 20.36 & 10.22 & 6.62 & 5.15 & 5.77 & 15.14 & 36.56 & 19.36 & 31.83 & Laguna Merín & -34.2166667 & -54.9333333 \\
\hline 10 & 58.85 & 23.17 & 20.38 & 9.49 & 6.67 & 5.14 & 5.91 & 13.36 & 34.05 & 17.71 & 30.38 & Laguna Merín & -33.45 & -54.5333333 \\
\hline 17 & 55.34 & 20.79 & 18.85 & 9.01 & 5.83 & 4.35 & 6.03 & 13.09 & 33.2 & 18.38 & 27.91 & Río de la Plata & -34.5333333 & -55.4 \\
\hline 95 & 55.97 & 22.51 & 19.37 & 9.79 & 6.01 & 5.34 & 6.1 & 14.08 & 36.71 & 19.3 & 30.35 & - & - & - \\
\hline 51 & 64.25 & 23.89 & 21.04 & 9.01 & 6.56 & 5.68 & 6.35 & 1 & 37.26 & 20.03 & 32.14 & Río Santa & 4.583 & 66.483 \\
\hline 691 & 62.54 & 23.65 & 21.93 & 9.78 & 5.99 & 4.82 & 6.66 & 15.12 & 37.23 & 19.27 & 32.74 & Río Santa Lucía & -34.3 & -55.25 \\
\hline 13 & 61.95 & 24.23 & 22.02 & 9.98 & 6.23 & 5.45 & 7.05 & 15.07 & 39.86 & 20.57 & 31.31 & - & - & - \\
\hline 26 & 55.4 & 21.27 & 18.16 & 8.59 & 6.15 & 4.98 & 5.05 & 12.29 & 32.81 & 16.98 & 28.63 & - & - & - \\
\hline 29 & 58.22 & 24.47 & 20.64 & 10.6 & & & & & & & & Laguna Merín & & \\
\hline 96 & 59.34 & 24.34 & 21.63 & 10.68 & 6.72 & 5.15 & 62 & 14.11 & 53 & 18.96 & 32.66 & Río Negro & -32.9166667 & -54.93 \\
\hline 1189 & 50.7 & 21.48 & 19.06 & 9.36 & 6.24 & 4.29 & 5.43 & 13.72 & 32.48 & 16.63 & 27.55 & Río de la Plata & -34.55 & -55.4 \\
\hline 1247 & 58.21 & 23.69 & 18.62 & 9.3 & 6.44 & 4.85 & 5.93 & 13.24 & 34.01 & 17.62 & 30.09 & Río Negro & -31.55 & -55.65 \\
\hline 1324 & 62.79 & 23.58 & 21.14 & 10.05 & 5.96 & 5.12 & 6.57 & 16.46 & 37.97 & 20.08 & 32.85 & Río de la Plata & -34.8333333 & -55.266 \\
\hline 414 & & 19.83 & & 8.23 & & & & & & 03 & 27.47 & & & 667 \\
\hline 1511 & 53.55 & 22.15 & 19.26 & 8.99 & 5.44 & 4.95 & 6.18 & 13.66 & 33.94 & 16.96 & 28.9 & Río Uruguay & -30.95 & -57.53333 \\
\hline 1523 & 54.17 & 22.39 & 19.45 & 9.14 & 6.29 & 5.14 & 6.07 & 14.3 & 34.84 & 18.28 & 29.76 & Río Uruguay & -30.9333333 & -57.5 \\
\hline 23088 & 51.71 & 21.63 & 18.21 & 9.03 & 5.44 & 4.39 & 5.56 & 13.14 & 33.35 & 18 & 27.64 & Río Negro & -31.0825 & -55.8555556 \\
\hline 23106 & 57.63 & 22.3 & 18.44 & 9.15 & 5.95 & 4.48 & 5.61 & 13.8 & 34.05 & 17.88 & 28.54 & Río Negro & -31.0466667 & -55.8477778 \\
\hline 23343 & 63.96 & 23.13 & 21.56 & 10.47 & 6.38 & 5.09 & 5.96 & 16.09 & 37.67 & 19.99 & 30.24 & Río Uruguay & -31.34177 & -56.66407 \\
\hline 23586 & 52.41 & 19.76 & 17.69 & 8.38 & 5.58 & 4.35 & 5.45 & 13.23 & 30.85 & 16.87 & 26.24 & Río Negro & -31.24676 & -55.95104 \\
\hline 23594 & 62.97 & 23.51 & 20.73 & 10.93 & 6.22 & 5.05 & 6.05 & 16.73 & 38.83 & 20.27 & 30.86 & Río de la Plata & -34.63791 & -55.24744 \\
\hline 23597 & 59.13 & 24.32 & 19.78 & 9.62 & 5.53 & 4.97 & 6.18 & 16.01 & 38.56 & 19.73 & 32.41 & Río de la Plata & -34.63791 & -55.24744 \\
\hline 23598 & 61.58 & 24.06 & 20.24 & 10.03 & 6.26 & 4.83 & 5.61 & 15.66 & 39.35 & 20.65 & 31.31 & Río de la Plata & -34.63791 & -55.24744 \\
\hline 23601 & 57.31 & 21.11 & 20.28 & 9.98 & 6.98 & 5.54 & 5.91 & 14.67 & 34.53 & 19.02 & 27.79 & Río Uruguay & -31.15043 & -56.29138 \\
\hline 23608 & 51.35 & 19.98 & 17.87 & 8.53 & 5.27 & 4.2 & 5.51 & 13.75 & 31.87 & 16.84 & 27.77 & Río Negro & -31.09436 & -55.96907 \\
\hline 23609 & 53.88 & 21 & 17.86 & 9.19 & 5.64 & 4.65 & 5.38 & 13.48 & 31.98 & 17.19 & 26.15 & Río Negro & -31.13739 & -56.04582 \\
\hline 23610 & 49.82 & 20.95 & 17.37 & 9.41 & 5.07 & 4.27 & 5.1 & 12.68 & 30.21 & 16.54 & 25.1 & Río Negro & -31.16724 & -55.87382 \\
\hline 23611 & 51.82 & 19.7 & 16.95 & 8.2 & 5.33 & 3.69 & 4.92 & 11.85 & 30.39 & 15.66 & 26.12 & Río Negro & -31.09436 & -55.96907 \\
\hline
\end{tabular}




\section{APPENDIX 3}

Forty four mature males $\left(\sigma^{\top}\right)$ of Limnomedusa macroglossa used in the analyses and their respective morphometric measurements, basin and latitude/longitude form Uruguay. ZVC-B: vertebrate collection of the Faculty of Sciences, University of the Republic. SVL: snout-vent length; MW: mandibular width; HL: head length; IOD: inter-orbital distance; ED: eye diameter; IND: inter-narial distance; END: eyenostril distance; ARML: arm length; TiL: tibia length; TaL: tarsus length; MtL: metatarsus length.

\begin{tabular}{|c|c|c|c|c|c|c|c|c|c|c|c|c|c|c|}
\hline $\begin{array}{l}\text { ACRONYM } \\
\left.\text { (Adult } 0^{7}\right)\end{array}$ & SVL & MW & $\mathrm{HL}$ & IOD & ED & IND & END & ARML & TiL & $\mathrm{TaL}$ & $\mathrm{MtL}$ & Basin & Latitude & Longitude \\
\hline 90 & 46.51 & 17.73 & 16.14 & 7.78 & 4.83 & 3.92 & 4.41 & 11.49 & 28.95 & 14.71 & 23.95 & - & - & - \\
\hline 140 & 46.71 & 17.01 & 15.67 & 7.22 & 4.17 & 3.39 & 4.38 & 11.56 & 28.44 & 15.38 & 25.62 & Río Uruguay & -30.2833333 & -57.1833333 \\
\hline 329 & 57.13 & 22.88 & 20.3 & 9.41 & 6.11 & 5.22 & 5.57 & 13.81 & 35.57 & 17.97 & 31.82 & Río Santa Lucía & -34.0666667 & -56.8833333 \\
\hline 357 & 52.61 & 21.27 & 17.88 & 8.58 & 6.31 & 4.96 & 4.98 & 13.78 & 31.25 & 16.25 & 29.04 & Río Uruguay & -33.4666667 & -58.4 \\
\hline 549 & 51.73 & 19.68 & 18.28 & 7.85 & 5.04 & 3.7 & 5.52 & 13.38 & 32.51 & 17.24 & 26.8 & Océano Atlántico & -34.8166667 & -54.9166667 \\
\hline 588 & 42.8 & 17.04 & 15.5 & 7.35 & 4.68 & 4.23 & 4.93 & 11.34 & 26.87 & 15.47 & 23.72 & - & - & - \\
\hline 908 & 44.37 & 19 & 16.85 & 7.36 & 5.35 & 3.86 & 4.54 & 11.68 & 26.7 & 13.91 & 23.7 & Río Santa Lucía & -34.5833333 & -56.4833333 \\
\hline 121 & 50.87 & 19.84 & 17.73 & 9.15 & 5.65 & 4.28 & 5.3 & 12.6 & 31.87 & 14.64 & 27.81 & - & - & - \\
\hline 156 & 53.16 & 24.28 & 20.98 & 9.15 & 6.57 & 5.14 & 5.6 & 13.37 & 35.33 & 18.7 & 31.68 & Océano Atlántico & -34.7333333 & -54.9833333 \\
\hline 1195 & 58.65 & 23.76 & 19.77 & 9.82 & 6.07 & 5.48 & 6.33 & 15.62 & 37.72 & 17.12 & 31.93 & Río Uruguay & -33.85 & -57.7333333 \\
\hline 1245 & 43.22 & 16.99 & 14.73 & 7.99 & 5.56 & 4.25 & 5.07 & 11.38 & 27.78 & 14.87 & 24.29 & Laguna Merín & -33.1 & -54.7 \\
\hline 1342 & 45.21 & 18.21 & 16.38 & 7.88 & 4.88 & 4.01 & 5.1 & 11.89 & 29.07 & 15.27 & 26.89 & Río Uruguay & -30.9333333 & -57.5 \\
\hline 120 & 60.92 & 22.81 & 19.61 & 9.82 & 7.2 & 5.24 & 5.86 & 13.81 & 36.88 & 18.72 & 30.62 & Río de la Plata & -34.86666667 & -56.3666667 \\
\hline 2124 & 56.47 & 22.36 & 18.85 & 9.45 & 6.55 & 5.14 & 5.58 & 17 & 33.2 & 18.02 & 30.36 & Río de la Plata & -34.86666667 & 6667 \\
\hline 2853 & 44.19 & 17.68 & 14.71 & 7.48 & 5.03 & 3.47 & 4.04 & 10.51 & 24.7 & 13.57 & 21.96 & Río Negro & -31.1166667 & -55.9833333 \\
\hline 3013 & 47.1 & 18.95 & 16.45 & 7.9 & 5.27 & 3.84 & 4.11 & 12.36 & 28.96 & 14.88 & 24.44 & Río Uruguay & -31.8166667 & -56.4166667 \\
\hline 3444 & 52.17 & 20.43 & 17.24 & 9 & 6.06 & 4.66 & 5.19 & 12.08 & 31.68 & 16.82 & 27.14 & - & - & - \\
\hline 3456 & 57.54 & 22.25 & 18.64 & 9.25 & 6.38 & 4.66 & 5.49 & 13.94 & 34.61 & 17.21 & 29.78 & Río de la Plata & -34.3333333 & -57 \\
\hline 4902 & 49.53 & 20.28 & 17.77 & 8.62 & 5.22 & 4.42 & 5.21 & & 35 & 17.93 & 04 & - & - & - \\
\hline 10254 & 51.5 & 21.19 & 17.31 & 8.98 & 5.5 & 4.29 & 5.55 & 12.59 & 32.01 & 16.81 & 28.36 & - & - & - \\
\hline 10278 & 54.01 & 21.24 & 18.81 & 9.02 & 5.61 & 5.09 & 6.08 & 13.8 & 33.59 & 16.78 & 27.94 & - & - & - \\
\hline 10279 & 53.21 & 20.67 & 18.29 & 9.78 & 5.9 & 5.05 & 5.99 & 13.94 & 34.98 & 18.38 & 28.82 & - & - & - \\
\hline 10845 & 55.79 & 21.99 & 17.15 & 8.96 & 5.71 & 4.39 & 4.97 & 13.66 & 34.23 & 17.17 & 30.09 & - & - & - \\
\hline 23105 & 45.68 & 18.31 & 16.37 & 7.78 & 5 & 3.56 & 4.18 & & 27.58 & 15.04 & 25.23 & Río Negro & -31.0466667 & -55.8477778 \\
\hline 23341 & 46.66 & 18.33 & 15.81 & 7.43 & 5.27 & 4.06 & 4.52 & 10.82 & 26.64 & 13.76 & 23.12 & Río Uruguay & -31.60659 & -56.43186 \\
\hline 23358 & 48.55 & 18.87 & 15.91 & 7.86 & 5.54 & 3.81 & 4.64 & 12.15 & 29.37 & 15.63 & 25.83 & Río de la Plata & -34.471741 & -55.529168 \\
\hline 23583 & 49 & 18.48 & 16.49 & 8.44 & 5.11 & 4.07 & 5.08 & 12.6 & 29.33 & 15.42 & 27.6 & Río Negro & -31.18738 & -55.9483 \\
\hline 23587 & 52.19 & 19.95 & 18.14 & 8.46 & 5.89 & 3.93 & 4.99 & 95 & 32.14 & 17.52 & 27.27 & Negro & -31.23 & 116 \\
\hline 23588 & 49.49 & 19.95 & 16.74 & 8.94 & 5.38 & 4.16 & 5.03 & 12.56 & 29.73 & 16.2 & 27.03 & Río Negro & -31.3044 & -56.05855 \\
\hline 23589 & 48.9 & 19.61 & 17.14 & 8.4 & 5.69 & 3.83 & 4.64 & 12.12 & 29.64 & 15.61 & 25.81 & Río Negro & -31.30467 & -56.05854 \\
\hline 23590 & 41.29 & 17.28 & 14.47 & 7.43 & 4.26 & 3.26 & 4.16 & 11.2 & 25.46 & 14.29 & 22.07 & Río Negro & -31.32815 & -56.17757 \\
\hline 23591 & 50.04 & 18.75 & 17.04 & 8.95 & 4.64 & 4.11 & 5.11 & 11.92 & 28.91 & 15.88 & 25.02 & Río Negro & -31.69442 & -56.12402 \\
\hline 23592 & 47.05 & 17.24 & 15.46 & 7.54 & 5.48 & 3.57 & 4.01 & 10.48 & 28.59 & 14.85 & 25.16 & Río Santa Lucía & -34.28159 & -55.27949 \\
\hline 23593 & 52.11 & 20.85 & 17.79 & 9.52 & 6.91 & 4.52 & 4.83 & 13.22 & 33.38 & 17.23 & 28.57 & Río Santa Lucía & -34.28159 & -55.27949 \\
\hline 23595 & 48.21 & 20.16 & 16.79 & 8.05 & 4.98 & 4.21 & 5.17 & 12.63 & 30.95 & 16.81 & 25.31 & Río de la Plata & -34.63791 & -55.24744 \\
\hline 23596 & 51.53 & 19.58 & 17.17 & 8.37 & 4.94 & 4.25 & 5.19 & 12.33 & 31.21 & 16.74 & 25.11 & Río de la Plata & -34.63791 & -55.24744 \\
\hline 23599 & 52.37 & 20 & 17.48 & 8.41 & 5.65 & 4.56 & 5.41 & 13.77 & 32.47 & 17.47 & 26.21 & Río Uruguay & -30.67911 & -56.51333 \\
\hline 23600 & 55.14 & 21.15 & 19.55 & 9.06 & 6.29 & 4.45 & 5.37 & 14.37 & 33.82 & 18.33 & 27.39 & Río Uruguay & -30.67911 & -56.51333 \\
\hline 23602 & 45 & 19.81 & 17.11 & 8.35 & 4.91 & 3.84 & 4.94 & 10.97 & 28.12 & 14.49 & 24.95 & Río Negro & -31.19047 & -55.90129 \\
\hline 23603 & 48.79 & 18.62 & 16.56 & 8.13 & 5 & 3.75 & 5.12 & 12.3 & 29.26 & 15.55 & 26.65 & Río Negro & -31.19068 & -55.90163 \\
\hline 23604 & 48.13 & 19.05 & 16.68 & 8.06 & 4.94 & 3.96 & 5.08 & 11.45 & 29.42 & 15.87 & 25.33 & Río Negro & -31.19068 & -55.90163 \\
\hline 23605 & 44.46 & 17.86 & 16.14 & 7.79 & 4.96 & 3.74 & 4.52 & 11.45 & 26.73 & 13.78 & 22.39 & Río Negro & -31.18738 & -55.9483 \\
\hline 23606 & 43.54 & 16.61 & 15.16 & 7.1 & 4.72 & 3.63 & 4.31 & 11.53 & 25.93 & 14.24 & 22.67 & Río Negro & -31.18738 & -55.9483 \\
\hline 23607 & 43.11 & 17.04 & 14.79 & 7.05 & 4.66 & 3.81 & 4.6 & 9.93 & 25.46 & 13.86 & 21.82 & Río Negro & -31.13739 & -56.04582 \\
\hline
\end{tabular}

